\begin{tabular}{|c|c|c|}
\hline & Int.J.Curr.Microbiol.App.Sci (2021) 10(10): $444-453$ & \\
\hline & $\begin{array}{l}\text { International Journal of Current Microbiology and Applied Sciences } \\
\text { ISSN: 2319-7706 Volume } \mathbf{1 0} \text { Number } \mathbf{1 0}(\mathbf{2 0 2 1 )} \\
\text { Journal homepage: } \underline{\text { http://www.ijcmas.com }}\end{array}$ & 30 \\
\hline $\begin{array}{l}\text { EXCELLENT } \\
\text { PUBLISHERS }\end{array}$ & & \\
\hline
\end{tabular}

\title{
Resource Use Efficiency and Economics of Garlic Cultivation in Saurashtra Region of Gujarat, India
}

\author{
Harshil Piyushbhai Sojitra* and N. J. Ardeshna \\ Department of Agricultural Economics, Junagadh Agricultural University, \\ Junagadh (Gujarat), India \\ *Corresponding author
}

\section{Keywords}

Garlic, cost-returns, profitability, resource use efficiency

Article Info

\section{Accepted:}

18 September 2021

Available Online:

10 October 2021
The present investigation was undertaken with a view to study the cost \& returns and resource use efficiency of garlic in Saurashtra region of Gujarat as it has the largest share in garlic cultivation with a random sample of 128 respondents. The results indicated that the average total cost of cultivation per hectare of garlic farms was Rs. 134523 which was the highest on large farms and the lowest on marginal farms. On an average, Cost-A (paid out cost) formed 68.23 percent of total cost, while Cost-B accounted for 84.75 percent of total cost. The average yield of garlic per hectare was 77.79 quintal on sample farms which gave Rs. 149960, Rs. 58177, Rs. 35950 and Rs. 49898 as gross income, farm business income, family labour income and farm investment income, respectively to selected garlic growers. The average cost of production $\left(\right.$ Cost- $\left.\mathrm{C}_{2}\right)$ was Rs. 1729.34 per quintal which was the highest on small farms, followed by large, marginal and medium category of farms. The variables of manures \& cakes, human labour and fertilizers found to have significant influence on the gross income. The sum of the elasticity's was less than one indicating diminishing returns to scale. The ratio of MVP to factor cost in case of all farms found to be greater than one for manures \& cakes, human labour and seed indicating that still there exists a scope for higher utilization of these inputs in order to increase the gross income. There is need to put more efforts to train the farmers regarding the use of pest and disease resistant varieties and creating awareness among the farmers regarding the efficient utilization of underutilized resources are some of the suggestions emerge from the study.

\section{Introduction}

Garlic is one of the important horticultural crop enhance farmers' economy with the pace of agricultural development in Indian economy. It is grown mainly for its bulb, which is used in every home as a constituent of meal. In India, garlic occupied 3.16 lakh hectares area with production of about 16.10 lakh metric tonnes in 2017-18 (Anon., 2019c). Moreover, area, production and yield of garlic crop grown considerably in India during last decade but it found quite unstable due to fluctuation in prices and several other factors. 
Gujarat is the leading garlic producing state in India with the highest productivity of 5.08tonnes/ha in year 2017-18. The area and production of garlic was about 0.19 lakh hectares and 1.51 lakh tonnes, respectively during the year 2017-18 in Gujarat (Anon., 2019a).

It is also noteworthy that Saurashtra region alone contributes area of 0.09 lakh hectares in garlic cultivation and 0.71 lakh tonnes of garlic production in year 2018-19. Junagadh and Morbi districts topped the list in terms of the average area and production of garlic in three consecutive years i.e., 2016-17 to 201819 (Anon., 2019b).Keeping all this in view, the present study was undertaken to work out the cost of production and input-output ratio, to estimate different profitability measures and to analyze the resource use efficiency of garlic growers in Saurashtra region of Gujarat state.

\section{Materials and Methods}

Junagadh and Morbi district were selected purposively, as it collectively covers 45.35 per cent area of garlic cultivation with 46.61 per cent share in production of garlic in the state in the year 2018-19. Junagadh and Visavadar talukas of Junagadh district and Morbi and Halvadtalukas of Morbi district were selected on the basis of its largest share in garlic cultivation in the district.

Two villages from each selected taluka were selected on the basis of concentration of area under garlic cultivation. A sample of 128 respondents comprises of 16 respondents of marginal, small, medium and large category from each of the selected district was selected for study. They are classified in to four different farm size groups viz., Marginal (up to 1.00 hectare), Small $(>1.00$ to 2.00 hectares), Medium (>2.00 to 4.00 hectares) and Large (above 4.00 hectares). The collected data were analysed using ratios and percentages to work out the standardized concepts of different costs and returns in addition to production function to work out the resource use efficiency. Different cost viz; Cost-A, Cost-B, Cost- $\mathrm{C}_{1}$ and Cost- $\mathrm{C}_{2} /$ Yield of main Product in quintal estimated and the various income measures used in the present study are shown as; Value of gross output, Farm business income, Family labour income, Intensive income, Farm investment income and Net income. In order to determine the efficiency of resources used in the production of garlic, the following form of Cobb-Douglas production function was fitted.

$\mathrm{Y}=\mathrm{ax} 1^{\mathrm{b} 1} \times 2^{\mathrm{b} 2} \times 3^{\mathrm{b} 3} \ldots \ldots . . \times \mathrm{n}^{\mathrm{bn}}$

The original equation was converted into log linear from and the parameters will be estimated by using the ordinary least square method.

$\ln Y=\ln a+b_{1} \ln X_{1}+b_{2} \ln X_{2}+b_{3} \ln X_{3}+$ $b_{4} \ln X_{4}+b_{5} \ln X_{5}+b_{6} \ln X_{6}+b_{7} \ln X_{7}+e$

where,

$\mathrm{Y}=$ Gross income of garlic (Rs. /ha)

$\mathrm{X}_{1}=$ Cost of human labour (Rs. /ha)

$\mathrm{X}_{2}=$ Cost of bullock and machine power (Rs. /ha)

$\mathrm{X}_{3}=$ Cost of manures (Rs. /ha)

$\mathrm{X}_{4}=$ Cost of planting materials (Rs. /ha)

$\mathrm{X}_{5}=$ Cost of fertilizers (Rs. /ha)

$\mathrm{X}_{6}=$ Cost of plant protection chemicals (Rs. /ha)

$\mathrm{X}_{7}=$ Irrigation charges $(\mathrm{Rs} . / \mathrm{ha})$

$\mathrm{a}=$ Intercept 
$b_{1}, b_{2} \ldots b_{7}=$ Regression coefficient (output elasticity of respective inputs (Xi's)

$\mathrm{e}=$ Error term with usual assumptions

\section{Results and Discussion}

The component wise costs for garlic cultivation on different farm size of farms per hectare are studied and results are furnished in Table 1. It was observed that at overall level, per hectare total cost was Rs. 134523. The per hectare highest cost was found to be Rs. 136791 in case of large farms followed by Rs. 135287 on medium farms, Rs. 134331 on small farms and Rs. 131682 on marginal farms. These results are in conformity with the findings of Patidar et al., (2018). They observed that per hectare total cost of garlic was Rs. 126807 in Ratlam district of Madhya Pradesh. On an overall basis, out of total costs of cultivation of garlic, the maximum share was of cost of seed (20.33 per cent) followed by the share of cost of human labour (20.22 per cent), fertilizer (8.26 per cent), irrigation charges (7.27 per cent), manures and cakes (5.91 per cent), tractor charges (4.74 per cent), insecticides/pesticides (4.26 per cent), depreciation cost ( 0.53 per cent) and bullock labour ( 0.25 per cent). The highest not payable in cash but accounted expenditure was of rental value of owned land (15.61 per cent) followed by managerial cost ( 9.09 per cent), interest on working capital (2.60 per cent) and interest on fixed capital ( 0.93 per cent).The results also indicated that the share of family and bullock labour was found declining while the share of tractor was found increasing in the total cost according to farm size. Similar trend was also observed in the use of fertilizers and manures \& cakes which increased with increase in farm size.

Estimates of different costs such as Cost-A, Cost-B, Cost- $\mathrm{C}_{1}$ and Cost- $\mathrm{C}_{2}$ were calculated and presented in Table 2. It could be inferred from the table that overall per hectare Cost-A was Rs. 91782. It was found to be the highest on large farms (Rs. 93946/ha) and lowest on marginal farms (Rs. 88983/ha). Further, the results also showed that Cost-B and Cost- $\mathrm{C}_{1}$ accounted for about 84.75 and 90.91 per cent of the Cost- $\mathrm{C}_{2}$. Overall, Cost- $\mathrm{C}_{2}$ was Rs. 134518 per hectare which was the highest on large farms (Rs. 136791/ha) and the lowest on marginal farms (Rs. 131682/ha). Increasing trend was observed in total cost $\left(\operatorname{Cost}-\mathrm{C}_{2}\right)$ which increased with increase in farm size from marginal to large. Higher cost on large farms were associated with intensive use of hired labour, seed and irrigation charges. These results are in conformity with the findings of Solanki (2018). He observed the total cost of garlic to the tune of Rs. 130990/ha at Barwani district of Madhya Pradesh in 2017-18. The average yield of garlic was 77.79 quintals per hectare on overall farms. It ranged from 76.33 quintals on marginal farms to 89.07 quintals on large farms (Table 3). Higher yield level on large farms may be due to efficient level of inputs utilized by them along with timely weeding operations, seed treatment, advance plant protection and proper selection of varieties of garlic, which affect the output to a greater extent, as compared to other farms. The variation in the yield might be due to the different time of sowing, types of land, use of improved variety and proper management etc. The result also indicated that per quintal average farm harvest price received by the garlic growers was Rs. 1927.27. The large size growers realized higher prices per quintal (Rs. 1976.14) followed by medium (Rs. 1944.60), small (Rs. 1917.44) and marginal (Rs. 1870.92) category of farmers. Generally, large growers sell their produce at higher prices compared to other category of farmers mainly due to their retention capacity, time of sale, selection of agencies to which the produce sold. Moreover, as the category of farms changed from marginal to large, the risk 
bearing ability and bargaining power increases, hence they sell their produce to distance market at higher price. The overall average gross return per hectare on garlic farms amounted to Rs. 149960 which varied from (Rs. 142807) on marginal farms to (Rs. 156253) on large farms. Thus, gross income also increased with increase in size of the farms.

A perusal of Table 4 shows that per hectare net returns over operational cost (Cost-A) was the highest (Rs. 62307) on large farms and the lowest (Rs. 53824) on marginal farms with on an average of about Rs. 58177 on overall sample farms. Net returns on overall farms over Cost-B, Cost- $\mathrm{C}_{1}$ and Cost- $\mathrm{C}_{2}$ were Rs. 35950, Rs. 27671 and Rs. 15442 per hectare, respectively. It is apparent from the analysis that per hectare net returns on garlic farm over Cost- $\mathrm{C}_{2}$ ranged from Rs. 11125 on marginal farms to Rs. 19462 on large farms with an average of Rs. 15442. Net income over different costs on garlic farms increased with increase in the size of farms. It is apparently clear from the results of net income as well as the need of human labour in cultivation of garlic has vast potential of generating employment and income for farmers.

The overall per hectare farm business income, family labour income, farm investment income and intensive income are given in Table 5. It was Rs. 58177, Rs. 35950, Rs. 49898 and Rs. 37674, respectively on all farms. The net profit per hectare over Cost- $\mathrm{C}_{2}$ was Rs. 15442 on all farms. The results also revealed brought that farm business income, family labour income, farm investment and intensive income as well as net profit increased as the category of farms changed from marginal to large farms.

Cost-price relationship generally decides the economic prosperity and the degree of commercialization on the farm. Given the price, offered by the market mechanism to a unit of output, the farmers' prosperity depends upon his capacity to produce his output at a lesser cost than the market price. The estimated cost of production per quintal of garlic is given in Table 6. The overall paid out cost (Cost-A) per quintal was Rs. 1179.85, which was 68.23 per cent to total cost. The overall Cost-B was Rs. 1465.53 per quintal which was 84.74 per cent of total cost. The overall cost of production $\left(\right.$ Cost- $\left.\mathrm{C}_{2}\right)$ per quintal of garlic varied from Rs. 1725.17 to Rs. 1730.00 on different farms with an average of Rs. 1729.34 on sample farms.

The input-output ratio reflects the criteria for economic viability of the crop based on gross return per rupee invested. The overall inputoutput ratio found to be $1: 1.11$ on the basis of Cost $-\mathrm{C}_{2}$ indicated that an investment worth Rs. 1.00 on all the inputs used in cultivation of garlic yielded an output worth Rs. 1.11 (Table $7)$. The input output ratio was the lowest (1:1.08) on marginal farms and it was the highest (1:1.14) on large farms. Further, it was observed that the input output ratio on the basis of Cost-A i.e., paid out cost was the highest $(1: 1.66)$ on large farms followed by medium farms (1:1.65), small farms (1:1.61) and marginal farms (1:1.60). The overall input output ratio over Cost-A, Cost-B, Cost- $\mathrm{C}_{1}$ and Cost- $\mathrm{C}_{2}$ was 1.63, 1.31, 1.23 and 1.11, respectively. Result indicated that on an average, the farmers got Rs. 1.11 per rupee invested. Thus, looking to the yield, gross return, net return and input output ratio of all categories of farms, it is concluded that garlic cultivation is considered more profitable for farmers of Saurashtra region.

The elasticity's of production with its standard errors are presented in Table 8. The coefficient of multiple determination (0.86) showed that 86 per cent of the variation in the gross income was accounted for by the independent variables included in the function. 
Table.1 Break-up of the total cost of cultivation for garlic (Rs/hectare)

\begin{tabular}{|c|c|c|c|c|c|c|}
\hline Sr No. & Item & \multicolumn{5}{|c|}{ Farm size } \\
\cline { 2 - 7 } & & Marginal & Small & Medium & Large & Overall \\
\hline $\mathbf{1 .}$ & Human labour & 26477 & 27119 & 27415 & 27817 & 27207 \\
& & $(20.11)$ & $(20.19)$ & $(20.26)$ & $(20.34)$ & $(20.22)$ \\
\hline & (a) Family & 9620 & 8331 & 7803 & 7362 & 8279 \\
& & $(7.31)$ & $(6.20)$ & $(5.77)$ & $(5.38)$ & $(6.15)$ \\
\hline & (b) Hired & 16858 & 18788 & 19612 & 20455 & 18928 \\
\hline & & $(12.80)$ & $(13.99)$ & $(14.50)$ & $(14.95)$ & $(14.07)$ \\
\hline $\mathbf{2 .}$ & Bullock labour & 908 & 305 & 127 & 31 & 343 \\
\hline $\mathbf{3 .}$ & Tractor charges & $(0.69)$ & $(0.24)$ & $(0.09)$ & $(0.02)$ & $(0.25)$ \\
\hline & & 6084 & 6387 & 6458 & 6567 & 6374 \\
\hline $\mathbf{4 .}$ & Seed & $(4.62)$ & $(4.75)$ & $(4.77)$ & $(4.80)$ & $(4.74)$ \\
\hline & & $(20.88)$ & $(20.53)$ & $(20.12)$ & $(19.81)$ & $(20.33)$ \\
\hline $\mathbf{5 .}$ & Manures and cakes & 7593 & 7889 & 8080 & 8251 & 7953 \\
& & $(5.77)$ & $(5.87)$ & $(5.98)$ & $(6.03)$ & $(5.91)$ \\
\hline $\mathbf{6 .}$ & Fertilizers & 11009 & 11033 & 11115 & 11309 & 11116 \\
& & $(8.36)$ & $(8.21)$ & $(8.22)$ & $(8.27)$ & $(8.26)$ \\
\hline $\mathbf{7 .}$ & Irrigation charges & 9329 & 9730 & 9903 & 10142 & 9776 \\
& & $(7.08)$ & $(7.24)$ & $(7.32)$ & $(7.41)$ & $(7.27)$ \\
\hline $\mathbf{8 .}$ & Insecticides/pesticides & 5625 & 5781 & 5750 & 5781 & 5734 \\
& & $(4.27)$ & $(4.30)$ & $(4.25)$ & $(4.23)$ & $(4.26)$ \\
\hline $\mathbf{9 .}$ & Depreciation cost & 681 & 714 & 720 & 726 & 710 \\
& & $(0.52)$ & $(0.53)$ & $(0.53)$ & $(0.53)$ & $(0.53)$ \\
\hline $\mathbf{1 0 .}$ & Interest on working capital & 3396 & 3499 & 3530 & 3585 & 3503 \\
& & $(2.58)$ & $(2.60)$ & $(2.61)$ & $(2.62)$ & $(2.60)$ \\
\hline $\mathbf{1 1 .}$ & Interest on fixed capital & 1115 & 1403 & 1243 & 1172 & 1233 \\
& & $(0.85)$ & $(1.04)$ & $(0.92)$ & $(0.86)$ & $(0.93)$ \\
\hline $\mathbf{1 2 .}$ & Rental value of owned land & 19993 & 20695 & 21434 & 21875 & 20999 \\
& & $(15.18)$ & $(15.41)$ & $(15.84)$ & $(15.99)$ & $(15.61)$ \\
\hline $\mathbf{1 3 .}$ & Managerial cost & 11971 & 12210 & 12299 & 12436 & 12229 \\
& & $(9.09)$ & $(9.09)$ & $(9.09)$ & $(9.09)$ & $(9.09)$ \\
\hline $\mathbf{1 4 .}$ & Total & 131682 & 134331 & 135287 & 136791 & 134523 \\
& & $(100.00)$ & $(100.00)$ & $(100.00)$ & $(100.00)$ & $(100.00)$ \\
\hline
\end{tabular}

Note: Figures in parentheses indicate per cent to total 
Table.2 Estimation of different costs for garlic cultivation

\begin{tabular}{|c|c|c|c|c|}
\hline \multirow{2}{*}{ Farm size } & \multicolumn{4}{|c|}{ Different costs (Rs./hectare) } \\
\cline { 2 - 5 } & Cost-A & Cost-B & Cost-C & Cost-C \\
\hline \multirow{2}{*}{ Marginal } & 88983 & 110092 & 119711 & 131682 \\
& $(67.57)$ & $(83.60)$ & $(90.91)$ & $(100.00)$ \\
\hline Small & 91693 & 113771 & 122102 & 134312 \\
& $(68.27)$ & $(84.71)$ & $(90.91)$ & $(100.00)$ \\
\hline Medium & 92508 & 115184 & 122987 & 135286 \\
& $(68.38)$ & $(85.14)$ & $(90.91)$ & $(100.00)$ \\
\hline Large & 93946 & 116993 & 124356 & 136791 \\
& $(68.68)$ & $(85.53)$ & $(90.91)$ & $(100.00)$ \\
\hline All farms & 91782 & 114010 & 122289 & 134518 \\
& $(68.23)$ & $(84.75)$ & $(90.91)$ & $(100.00)$ \\
\hline
\end{tabular}

Note: Figures in parentheses indicate per cent to Cost- $\mathrm{C}_{2}$

Table.3 Yield level, harvest price and gross income per hectare

\begin{tabular}{|c|c|c|c|}
\hline Farm size & $\begin{array}{c}\text { Yield } \\
\text { (quintal) }\end{array}$ & $\begin{array}{c}\text { Harvest price } \\
\text { (Rs./quintal) }\end{array}$ & $\begin{array}{c}\text { Value of gross } \\
\text { output } \\
\text { (Rs.) }\end{array}$ \\
\hline Marginal & 76.33 & 1870.92 & 142807 \\
\hline Small & 77.02 & 1917.44 & 147681 \\
\hline Medium & 78.73 & 1944.60 & 153098 \\
\hline Large & 79.07 & 1976.14 & 156253 \\
\hline All farms & 77.79 & 1927.27 & 149960 \\
\hline
\end{tabular}

Table.4 Net gains over different costs per hectare

\begin{tabular}{|c|c|c|c|c|}
\hline \multirow{2}{*}{ Farm size } & \multicolumn{4}{|c|}{ Net gains over different costs (Rs./hectare) } \\
\cline { 2 - 5 } & Cost-A & Cost-B & Cost-C & Cost-C $_{\mathbf{2}}$ \\
\hline Marginal & 53824 & 32715 & 23096 & 11125 \\
\hline Small & 55988 & 33910 & 25579 & 13369 \\
\hline Medium & 60590 & 37914 & 30111 & 17812 \\
\hline Large & 62307 & 39260 & 31897 & 19462 \\
\hline All farms & 58177 & 35950 & 27671 & 15442 \\
\hline
\end{tabular}


Table.5 Farm business income, family labour income, farm investment income, net profit and intensive income (over Cost- $\mathrm{C}_{2}$ ) (Rs./hectare)

\begin{tabular}{|c|c|c|c|c|c|}
\hline \multirow{2}{*}{ Particulars } & \multicolumn{5}{|c|}{ Farm size } \\
\cline { 2 - 6 } & Marginal & Small & Medium & Large & All farms \\
\hline Farm business income & 53824 & 55988 & 60590 & 62307 & 58177 \\
\hline Family labour income & 32715 & 33910 & 37914 & 39260 & 35950 \\
\hline Farm investment income & 44204 & 47657 & 52787 & 54945 & 49898 \\
\hline Net profit & 11125 & 13369 & 17812 & 19462 & 15442 \\
\hline Intensive income & 32233 & 35467 & 40489 & 42509 & 37674 \\
\hline
\end{tabular}

Table.6 Cost of production per quintal on the basis of different cost

\begin{tabular}{|c|c|c|c|c|}
\hline \multirow{2}{*}{ Farm size } & \multicolumn{4}{|c|}{ Different costs (Rs./quintal) } \\
\cline { 2 - 5 } & Cost-A & Cost-B & Cost-C & Cost-C $_{\mathbf{2}}$ \\
\hline Marginal & 1165.77 & 1442.32 & 1568.33 & 1725.17 \\
& $(67.57)$ & $(83.60)$ & $(90.91)$ & $(100.00)$ \\
\hline Small & 1190.50 & 1477.16 & 1585.33 & 1743.86 \\
& $(68.27)$ & $(84.71)$ & $(90.91)$ & $(100.00)$ \\
\hline Medium & 1175.00 & 1463.03 & 1562.14 & 1718.35 \\
& $(68.38)$ & $(85.14)$ & $(90.91)$ & $(100.00)$ \\
\hline Large & 1188.13 & 1479.61 & 1572.73 & 1730.00 \\
& $(68.68)$ & $(85.53)$ & $(90.91)$ & $(100.00)$ \\
\hline All farms & 1179.85 & 1465.53 & 1572.13 & 1729.34 \\
& $(68.23)$ & $(84.74)$ & $(90.91)$ & $(100.00)$ \\
\hline
\end{tabular}

Note: Figures in parentheses indicate per cent to Cost- $\mathrm{C}_{2}$

Table.7 Input-output ratio over different costs

\begin{tabular}{|c|c|c|c|c|}
\hline Farm size & Cost-A & Cost-B & Cost-C $_{\mathbf{1}}$ & Cost-C $_{\mathbf{2}}$ \\
\hline Marginal & $1: 1.60$ & $1: 1.30$ & $1: 1.19$ & $1: 1.08$ \\
\hline Small & $1: 1.61$ & $1: 1.30$ & $1: 1.21$ & $1: 1.10$ \\
\hline Medium & $1: 1.65$ & $1: 1.33$ & $1: 1.24$ & $1: 1.13$ \\
\hline Large & $1: 1.66$ & $1: 1.34$ & $1: 1.26$ & $1: 1.14$ \\
\hline All farms & $1: 1.63$ & $1: 1.31$ & $1: 1.23$ & $1: 1.11$ \\
\hline
\end{tabular}


Table.8 Estimated Cobb Douglas production function of garlic

\begin{tabular}{|c|c|c|}
\hline Sr. No. & Variables & $\begin{array}{c}\text { Production } \\
\text { Elasticity (bi) }\end{array}$ \\
\hline 1. & $\mathrm{X}_{1}=$ Cost of human labour (Rs.) & $\begin{array}{l}1.094 * \\
(0.553)\end{array}$ \\
\hline 2. & $\mathrm{X}_{2}=$ Cost of bullock labour and tractor charges (Rs.) & $\begin{array}{c}-0.241 \\
(0.203)\end{array}$ \\
\hline 3. & $\mathrm{X}_{3}=$ Cost of manures and cakes (Rs.) & $\begin{array}{l}3.315 * \\
(1.744)\end{array}$ \\
\hline 4. & $\mathrm{X}_{4}=$ Cost of seed (Rs.) & $\begin{array}{c}2.020 \\
(4.115)\end{array}$ \\
\hline 5. & $\mathrm{X}_{5}=$ Cost of fertilizers (Rs.) & $\begin{array}{c}-4.821 * * \\
(1.933)\end{array}$ \\
\hline 6. & $\mathrm{X}_{6}=$ Cost of plant protection chemicals (Rs.) & $\begin{array}{l}-1.214 \\
(3.968)\end{array}$ \\
\hline 7. & $\mathrm{X}_{7}=$ Irrigation charges $(\mathrm{Rs})$. & $\begin{array}{c}0.576 \\
(0.790)\end{array}$ \\
\hline 8. & $\mathrm{a}=$ Constant & 2.451 \\
\hline 9. & $\mathrm{R}^{2}=$ Co-efficient of multiple determination & 0.86 \\
\hline 10. & $\sum b_{\mathrm{i}}{ }^{\prime} s=$ Returns to scale & 0.73 \\
\hline 11. & $\mathrm{n}=$ Number of farms & 128 \\
\hline
\end{tabular}

Note: Figures in parentheses indicate standard error of corresponding elasticity.

* Significant at $5 \%$ level of significance

** Significant at $1 \%$ level of significance

Table.9 Resource use efficiency of selected garlic growers

\begin{tabular}{|c|c|c|c|}
\hline Sr. No. & Variables & MVP & Level of resource use \\
\hline $\mathbf{1}$ & $\mathrm{X}_{1}=$ human labour (Rs.) & 1.27 & Under Utilization \\
\hline $\mathbf{2}$ & $\mathrm{X}_{2}=$ bullock labour and tractor (Rs.) & -0.33 & Over Utilization \\
\hline $\mathbf{3}$ & $\mathrm{X}_{3}=$ manures and cakes (Rs.) & 4.41 & Under Utilization \\
\hline $\mathbf{4}$ & $\mathrm{X}_{4}=$ seed (Rs.) & 2.35 & Under Utilization \\
\hline $\mathbf{5}$ & $\mathrm{X}_{5}=$ fertilizers (Rs.) & -6.17 & Over Utilization \\
\hline $\mathbf{6}$ & $\mathrm{X}_{6}=$ plant protection chemicals (Rs.) & -1.68 & Over Utilization \\
\hline $\mathbf{7}$ & $\mathrm{X}_{7}=$ Irrigation (Rs.) & 0.75 & Over Utilization \\
\hline
\end{tabular}

Note: MVP - Marginal Value Product

The conspicuous observation from the table is that the variables of fertilizers exert highly significant while human labour and manures \& cakes significant influence on the gross income. It implies that 1 per cent increase in organic manures \& cakes and human labour resulted in increase of 3.315 and 1.094 per cent in the gross income, respectively. The elasticity's of output with the human labour $(1.094 \%)$ and organic manures \& cakes $(3.315 \%)$ have turned out to be positive and significant at 5 per cent level in Saurashtra region. The elasticity of fertilizers $(4.821 \%)$ have the significant and negative effect on garlic output in the study area. The variable like expenses of cost of seed (2.020) and 
irrigation charges (0.576) were positive but non-significant. Regression coefficient of use of plant protection with the gross income of garlic (-1.214) has also found to negative and non-significant in the study area. The results were more accorded to the resume of work done by Chauhan (2004) and Ghumatkar (2003). Chauhan (2004) observed that the cost of manures was significant and positive at Indore district of Madhya Pradesh in 2004. Ghumatkar (2003) observed that the cost of seed was positive and non-significant at Pune district of Maharashtra in 2003. The sum of regression co-efficient was 0.73 , which being less than one indicated decreasing return to scale. In other words, sample farmers were observed to be operating in second zone of production.

The Cobb-Douglas Production function estimates and geometric levels of inputs were used to estimate the marginal value product. A neoclassical theory indicates that marginal value product (MVP) must be equal or above the unit price of respective input for profit maximization. This principle is used to examine the resource use efficiency for selected crop of garlic. The results of MVPs of garlic crop are given Table 9. It was observed that the MVP to MFC ratio of human labour (1.27), manures \& cakes (4.41) and seed (2.35) were more than one indicating underutilization of these resources in the cultivation of garlic in study area. It implies that farmers have opportunity to increase the yield of garlic by increasing the use of these inputs. The ratio of bullock labour and tractor $(-0.33)$, fertilizers $(-6.17)$, plant protection chemicals $(-1.68)$ and irrigation $(0.75)$ were less than one indicating over utilization of these resources in cultivation of garlic in study area. It indicated that farmers have to increase the yield of garlic by decreasing the use of these inputs. These results are in line with those of Diddi (2013) who found that MVP to MFC was positive and more than unity for seed and FYM in Kundagol and Ranebennurtaluka of Karnataka state.

\section{Policy implications}

The average total cost of cultivation per hectare of onion farms was the highest on large farms, followed by on medium, small and marginal farms. On an average Cost-A (paid out cost) formed 68.23 per cent of total cost, while Cost-B accounted for 84.75 per cent of total cost. The overall average gross returns per hectare of garlic farms amounted to Rs. 149960.00 which varied from Rs. 142807.00 on marginal farms to Rs. 156253.00 on large farms. Net returns on overall farms over Cost-A, Cost-B, Cost- $\mathrm{C}_{1}$ and Cost- $\mathrm{C}_{2}$ were Rs. 58177.00, Rs. 35950.00, Rs. 27671.00 and Rs. 15442.0 per hectare, respectively. The overall per hectare farm business income, family labour income and farm investment income were Rs. 58177, Rs. 35950 and Rs. 49898, respectively on overall farms.

The net profit per hectare (over Cost- $\mathrm{C}_{2}$ ) was Rs. 15442 on overall farms. The average cost of production $\left(\right.$ Cost- $\left.\mathrm{C}_{2}\right)$ was Rs. 1729.34 per quintal which was the highest on small farms followed by large farms, marginal farms and medium category of farms. The overall input output ratio found to be $1: 1.11$. The variables of human labour, manures and cakes and fertilizers found to have significant influence on the gross income with elasticity's of 1.094, 3.315 , and -4.821 per cent, respectively.

The sum of the value of regression coefficients of variables ( $\Sigma$ bi's) was 0.73 , indicating diminishing returns to scale. The ratio of MVP to factor cost in case of all farms found to be the highest for manures $\&$ cakes (4.41), followed by seed (2.35), human labour (1.27) and irrigation (0.75) indicating that still there exists a scope for higher utilization of these inputs in order to increase the gross 
income. Adoption of improved technologies along with proper utilization of resources like manures and fertilizers, irrigation, HYV seeds and better management would improve the yield and returns.

\section{References}

Anonymous. 2019a. Indian statistical database (online): https://www.indiastat.com. Accessed on: 20 September, 2019.

Anonymous. 2019b. Directorate of Horticulture, district wise area, production and yield of horticultural crops in Gujarat state. Government of Gujarat, Gandhinagar. https://doh.gujarat.gov.in. Accessed on: 20 September, 2019.

Anonymous. 2019c Directorate of Economics and Statistics, Department of Agricultural, Cooperation and Farmers Welfare, Government of India, New Delhi. Available at http://eands.dacnet.nic.in. Accessed on: 21 February, 2020.

Chauhan, H. 2004. Economics of production and marketing of garlic in Indore district of Madhya Pradesh. M.Sc.
(Agri.) Unpublished thesis submitted to Jawaharlal Nehru Krishi Vishwa Vidhyalaya, Jabalpur, Indore, Madhya Pradesh.

Diddi, S. N. 2013. Economics of production and marketing of garlic in North Karnataka. M.Sc. (Agri.) Unpublished thesis submitted to University of Agricultural Science, Dharwad.

Ghumatkar, A. B. 2003. Economics of production and marketing of garlic in Pune district of Maharashtra state. M.Sc. (Agri.) Unpublished thesis submitted to Marathwada Agricultural University, Parbhani.

Patidar, P. K.; Khan, N. and Kumar, S. 2018. Economic analysis of garlic cultivation in Ratlam district of Madhya Pradesh. International Journal of Agriculture, Environment and Biotechnology.11(2): 371- 377.

Solanki, J. 2018. A study on economic analysis of production and marketing of garlic in Barwani district of Madhya Pradesh. M.Sc. (Agri.) Unpublished thesis submitted to Rajmata Vijayaraje Scindia Krishi Vishwa Vidyalaya, Gwalior.

\section{How to cite this article:}

Harshil Piyushbhai Sojitra and Ardeshna, N. J. 2021. Resource Use Efficiency and Economics of Garlic Cultivation in Saurashtra Region of Gujarat, India. Int.J.Curr.Microbiol.App.Sci. 10(10): 444-453. doi: https://doi.org/10.20546/ijcmas.2021.1010.053 